\title{
Keabsahan Akta Autentik yang Mengandung Unsur Tindak Pidana Pemalsuan
}

\author{
Debby Dwi Arlingga \\ debbydwiarlingga@gmail.com
}

\begin{abstract}
Notary deed is the perfect, strongest, and most complete proof of evidence, thus not only guaranteeing legal certainty but also avoiding disputes. In practice, however, disputes often arise due to the existence of a notary deed. The notary can be liable for his action in making authentic deeds that are not in accordance with the applied provisions or are carried out against the law. This study has 2 formulations of the problem, first, how is the validity of the deed made before a notary containing fraudulent acts according to the Decision of Supreme Court Number $1003 \mathrm{~K} / \mathrm{PID} / 2015$, and second, how is the notary's liability for the notarial deed containing fraud. The method in this study is normative legal research. The results show that, first, based on the Decision of Supreme Court Number 1003 K/PID/2015 in conjunction with the decision of Pekanbaru District Court Number 247/Pdt.G/2016/PN.Pbr, the Notary Deed No. 149 dated March 30, 2011 is declared valid and valuable before the law, but in terms of the strength of evidence, it is degraded from authentic deed to private deed for violating Article 48, 49, 50, and 51 of Law on Notary concerning Investigators. Second, the notary's legal duty for the deed containing fraud includes criminal, civil, and administrative liabilities.
\end{abstract}

Keywords: Authentic deed; fraud; notary

\begin{abstract}
Abstrak
Akta Notaris merupakan alat pembuktian yang sempurna, terkuat dan penuh sehingga selain dapat menjamin kepastian hukum, akta Notaris juga dapat menghindari terjadinya sengketa. Tetapi dalam prakteknya, seringkali sengketa timbul sebagai akibat keberadaan sebuah akta Notaris. Notaris dapat dibebani tanggung jawab atas perbuatannya dalam membuat akta autentik yang tidak sesuai dengan ketentuan yang berlaku atau dilakukan secara melawan hukum. Pada penelitian ini terdapat 2 rumusan masalah yaitu: pertama, bagaimanakah keabsahan akta yang dibuat di hadapan Notaris yang mengandung unsur tindak pidana pemalsuan menurut Putusan Mahkamah Agung Nomor 1003 K/PID/2015; dan kedua, bagaimanakah tanggung jawab Notaris terhadap akta yang dibuat di hadapannya yang mengandung unsur tindak pidana pemalsuan. Metode penelitian dalam penelitian ini adalah penelitian hukum normatif. Hasil penilitian yaitu: pertama, berdasarkan Putusan Mahkamah Agung Nomor 1003 K/PID/2015 jo. Putusan Pengadilan Negeri PekanbaruNomor 247/Pdt.G/2016/PN.Pbr, akta Notaris Nomor 149 tanggal 30 Maret 2011 dinyatakan sah dan berharga menurut hukum, namun dari segi kekuatan pembuktiannya, yang semula autentik terdegradasi menjadi akta di bawah tangan karena telah melanggar Pasal 48, 49, 50, dan 51 UUJN-P. Kedua, tanggung jawab Notaris terhadap akta yang dibuat di hadapannya yang mengandung unsur tindak pidana pemalsuan yaitu Notaris dapat dimintai pertanggungjawaban secara pidana, perdata dan administratif.
\end{abstract}

Kata-kata Kunci: Akta autentik; pemalsuan; notaris 


\section{Pendahuluan}

Akta Notaris merupakan alat pembuktian yang sempurna, terkuat dan penuh sehingga selain dapat menjamin kepastian hukum, akta notaris juga dapat menghindari terjadinya sengketa. Tetapi dalam prakteknya, seringkali sengketa timbul sebagai akibat keberadaan sebuah akta Notaris. Bahkan kasus-kasus pidana yang membawa Notaris sebagai tersangka adalah konsekuensi dari akta Notaris yang dibuatnya.

Sangat disayangkan bilamana terdapat akta-akta Notaris yang isinya dipermasalahkan, diragukan kebenarannya, dianggap bertentangan dengan hukum dan keadilan serta dirasakan merugikan kliennya karena ketidaksengajaan atau karena kurang menguasai dalam melaksanakan tugas dan jabatannya serta bertentangan dengan etika profesi Notaris. Notaris dapat dibebani tanggung jawab atas perbuatannya dalam membuat akta autentik yang tidak sesuai dengan ketentuan yang berlaku atau dilakukan secara melawan hukum.

Pencantuman nama Notaris dan tanda tangan Notaris oleh pihak penegak hukum sering ditafsirkan Notaris sebagai pihak dalam akta, sehingga ketika isi akta dipermasalahkan oleh mereka yang nama tersebut dalam akta atau oleh pihak lainnya, Notaris seringkali ditempatkan sebagai tergugat atau turut tergugat, atau juga ditempatkan sebagai saksi bahkan tersangka atau terdakwa. ${ }^{1}$ Seperti yang dialami oleh Neni Sanitra, Notaris di Pekanbaru yang terbukti secara sah melakukan tindak pidana pemalsuan akta autentik.

Kasus dimulai pada Maret 2011, PT. Bonita Indah diundang untuk mengikuti tender pengadaan 210 unit mobil ringan tanpa pengemudi yang akan disewakan ke PT. Chevron Pasifik Indonesia. Setelah mendapat undangan tersebut, Daniel Freddy Sinambela selaku Direktur PT. Bonita Indah mengadakan pertemuan untuk melakukan kerja sama dengan Bonar Saragih dan Mangapul Hutahean. Kesepakatan antara Daniel Freddy Sinambela dan Bonar Saragih serta Mangapul

${ }^{1}$ Habib Adjie, Kebatalan dan Pembatalan Akta Notaris, Cetakan Kesatu, Refika Aditama, Bandung, 2011, hlm. $1-2$ 
Hutahaean dilakukan di Kantor Notaris Neni Sanitra, SH., M.Kn. di jalan Tuanku Tambusai Kota Pekanbaru.

Dari hasil pertemuan tersebut, Notaris Neni Sanitra membuat doslag atau draf perjanjian kerjasama (minuta Akta Nomor 149, 30 Maret 2011). Setelah draf perjanjian kerjasama selesai dibuat, kemudian Notaris Neni Sanitra menyerahkan draf perjanjian tersebut kepada Daniel Freddy Sinambela sebagai Pihak Pertama, sedangkan Bonar Saragih dan Mangapul Hutahaean sebagai Pihak Kedua, untuk dibaca dan dipelajari, selanjutnya para pihak membawa pulang draf tersebut. Ketika Daniel Freddi Sinambela membaca dan mempelajari, ternyata terdapat kekeliruan pada Pasal 7 draf minuta akta Nomor 149, 30 Maret 2011 tersebut, lalu Daniel Freddy Sinambela meminta Notaris Neni Sanitra untuk memperbaikinya. Setelah draf minuta Akta Nomor 149, 30 Maret 2011 diperbaiki, kemudian Notaris Neni Sanitra membuat Minuta Akta Nomor 149, 30 Maret 2011 dengan bunyi Pasal 7 yang telah dirubah sesuai permintaan Daniel Freddy Sinambela.

Minuta Akta Nomor 149, 30 Maret 2011 diparaf dan ditandatangani oleh Pihak Pertama dan Pihak Kedua, namun Notaris Neni Sanitra belum menyerahkan salinan Minuta Akta tersebut kepada Pihak Pertama dengan alasan salinan Akta belum selesai dibuat. Atas kehendak Notaris sendiri, Pasal 4, Pasal 6, dan Pasal 9 diubah (tidak direnvoi), yaitu dihapus dengan menggunakan penghapus kemudian diketik ulang menggunakan mesin ketik. Perubahan tersebut oleh Notaris Neni Sanitra dilakukan untuk menyesuaikan perubahan pada Pasal 7. Perubahan pada Pasal 7 tersebut juga oleh Notaris Neni Sanitra lakukan dengan menggunakan mesin ketik, selain itu juga melakukan pencoretan pada Pasal 6.

Perubahan yang dilakukan Notaris Neni Sanitra pada Pasal 4, 6, 7 dan 9 pada minuta Akta Nomor 149, 30 Maret 2011 tidak sesuai dengan UUJN, yaitu Pasal 48, 49, 50 dan 51. Salinan Akta Notaris yang dibuat dan mengacu kepada minuta Akta yang telah diperbaiki tidak sesuai dengan prosedur atau dengan cara yang tidak benar. Terhadap perubahan yang dilakukan oleh Notaris Neni Sanitra tersebut, Daniel Freddy melaporkan Neni ke Majelis Pengawas Notaris Wilayah Provinsi Riau dan telah dilakukan sidang dengan putusan menyatakan pengaduan pelapor Daniel Freddy Sinambela dapat diterima; dan menghukum Notaris Neni Sanitra 
dengan teguran lisan karena telah menghapus, menindih dan menggantinya dengan yang lain terhadap Pasal 4, 6, 7 dan 9 Akta Nomor 149, 30 Maret 2011.

Suatu benda, tanda, merk, mata uang atau suatu tulisan dipandang sebagai telah dipalsukan secara materiil jika benda, tanda, merk, mata uang atau suatu tulisan yang semula asli itu telah diubah demikian rupa, sehingga mempunyai sifat yang lain dari sifatnya yang asli. ${ }^{2}$ Tindak pidana memalsukan atau membuat secara palsu suatu surat yang dapat menimbulkan suatu hak, suatu perikatan, suatu pembebasan utang atau yang dimaksud untuk membuktikan suatu kenyataan itu, merupakan tindak pidana pertama dari tindak pidana pemalsuan surat yang diatur dalam Bab ke-XII dari buku ke-II Kitab Undang-Undang Hukum Pidana (selanjutnya disebut KUHP). ${ }^{3}$

Tindak pidana pemalsuan akta autentik dan lain-lainnya dan kesengajaan menggunakan akta autentik dan lain-lain yang palsu atau dipalsukan oleh pembentuk undang-undang telah diatur di dalam Pasal 264 ayat (1) KUHP yang berbunyi: 4

(1) Pemalsuan surat diancam dengan pidana penjara paling lama delapan tahun, jika dilakukan terhadap:

1. akta-akta autentik;

2. surat hutang dan sertifikat hutang dari sesuatu negara atau bagiannya ataupun dari suatu lembaga umum;

3. surat sero atau hutang atau sertifikat sero atau hutang dari suatu perkumpulan yayasan, perseroan atau maskapai;

4. talon, tanda bukti diividen atau bunga dari salah satu surat yang diterangkan dalam 2 dan 3, atau tanda bukti yang dikeluarkan sebagai pengganti surat-surat itu;

5. surat kredit atau surat dagang yang diperuntukkan untuk diedarkan.

Notaris dalam membuat akta autentik berusaha semaksimal mungkin untuk membuat akta tidak mengalami cacat atau kesalahan. Jika terjadi penambahan atau pencoretan terhadap akta tersebut, maka berdasarkan Pasal 49 UUJN-P, setiap

2P.A.F. Lamintang dan Theo Lamintang, Delik-Delik Khusus Kejahatan Membahayakan Kepercayaan Umum Terhadap Surat, Alat Pembayaran, Alat Bukti, dan Peradilan, Cetakan Pertama, Edisi Kedua, Sinar Grafika, Jakarta, 2009, hlm. 5.

${ }^{3}$ Ibid., hlm. 6. hlm. 97.

${ }^{4}$ Moeljatno, Kitab Undang-Undang Hukum Pidana, Cetakan Kedua puluh delapan, Bumi Aksara, Jakarta, 2009, 
perubahan atas akta dibuat di sisi kiri atas. ${ }^{5}$ Apabila kalimat yang dicoret kemudian diganti begitu saja dengan penghapusan, pengetikan tindih, maka perubahan tersebut tidak sah dan melanggar hukum.

Pada persidangan sebelumnya, Pengadilan Negeri Pekanbaru melalui putusannya Nomor 906/Pid.B/2014/PN.Pbr., 25 Maret 2015 memutuskan: ${ }^{6}$

1. Menyatakan Terdakwa NENI SANITRA, S.H., M.Kn., terbukti melakukan perbuatan sebagaimana didakwa dalam dakwaan primer, namun bukan merupakan tindak pidana;

2. Melepaskan Terdakwa NENI SANITRA, S.H., M.Kn.,dari segala tuntutan hukum;

3. Memulihkan hak-hak Terdakwa dalam kemampuan, kedudukan, harkat serta martabatnya;

4. Membebankan biaya perkara kepada Negara.

Pada putusan Pengadilan Negeri Pekanbaru tersebut, Majelis Hakim menyatakan Notaris Neni Sanitra tidak terbukti melanggar hukum. Putusan pelepasan dari segala tuntutan hukum diatur dalam Pasal 191 ayat (2) Kitab Undang-undang Hukum Acara Pidana (KUHAP), yang berbunyi: "Jika pengadilan berpendapat bahwa perbuatan yang didakwakan kepada terdakwa terbukti tetapi perbuatan itu tidak merupakan suatu tindak pidana, maka terdakwa diputus lepas dari segala tuntutan hukum."7 Upaya hukum merupakan sarana untuk melaksanakan hukum, yaitu hak terpidana atau jaksa penuntut umum untuk tidak menerima penetapan atau putusan pengadilan, karena tidak merasa puas dengan penetapan atau putusan tersebut. ${ }^{8}$

Tidak terima dengan putusan Pengadilan Negeri Pekanbaru tersebut, Jaksa Penuntut Umum pada Kejaksaan Negeri Pekanbaru mengajukan permohonan kasasi dengan alasan bahwa Majelis Hakim Pengadilan Negeri Pekanbaru tidak menerapkan peraturan hukum dengan benar atau menerapkan peraturan hukum tidak sebagaimana mestinya.

\footnotetext{
hlm. 40 .

${ }^{5}$ Supriadi, Etika \& Tanggung Jawab Profesi Hukum Di Indonesia, Cetakan Keenam, Sinar Grafika, Jakarta, 2016,

${ }^{6}$ PT. Bonita Indah v. Neni Sanitra, Putusan Mahkamah Agung Nomor 1003 K/PID/2015, hlm. 16.

${ }^{7}$ M. Yahya Harahap, Pembahasan Permasalahan dan Penerapan KUHAP: Pemeriksaan Sidang Pengadilan, Banding, Kasasi dan Peninjauan Kembali, Edisi kedua, Sinar Grafika, Jakarta, 2005, hlm. 77.

${ }^{8}$ A.Hamzah dan Irdan Dahlan, Upaya Hukum Dalam Perkara Pidana, Bina Aksara, Jakarta, 1987, hlm. 3.
} 
Pada Tingkat Kasasi, Mahkamah Agung mengabulkan permohonan kasasi dari pemohon kasasi/ Jaksa Penuntut Umum, Membatalkan putusan Pengadilan Negeri Pekanbaru Nomor 906/Pid.B/2014/PN.Pbr, serta menyatakan terdakwa Neni Sanitra terbukti secara sah dan meyakinkan bersalah melakukan tindak pidana pemalsuan surat autentik.

Berdasarkan latar belakang tersebut di atas, maka peneliti tertarik untuk meneliti mengenai "Keabsahan Akta Autentik Yang Mengandung Unsur Tindak Pidana Pemalsuan (Studi Putusan Mahkamah Agung Nomor 1003 K/PID/2015)".

\section{Rumusan Masalah}

Rumusan masalah pada penelitian ini adalah: Pertama, bagaimanakah keabsahan akta yang dibuat di hadapan Notaris yang mengandung unsur tindak pidana pemalsuan dalam putusan Mahkamah Agung Nomor 1003 K/PID/2015? Kedua, bagaimanakah tanggung jawab Notaris terhadap akta yang dibuat di hadapannya yang mengandung unsur tindak pidana pemalsuan?

\section{Tujuan Penelitian}

Tujuan penelitian merupakan sasaran atau target mengenai yang hendak dicapai dalam melaksanakan penelitian. Berdasarkan pokok permasalahan seperti diuraikan di atas, penelitian ini bertujuan sebagai berikut: Pertama, untuk mengkaji keabsahan akta yang dibuat di hadapan Notaris yang mengandung unsur tindak pidana pemalsuan dalam putusan Mahkamah Agung Nomor 1003 K/PID/2015. Kedua, untuk menganalisis tanggung jawab Notaris terhadap akta yang dibuat di hadapannya yang mengandung unsur tindak pidana pemalsuan.

\section{Metode Penelitian}

Obyek penelitian ini adalah Keabsahan Akta Autentik Yang Mengandung Unsur Tindak Pidana Pemalsuan pada Putusan Mahkamah Agung Nomor 1003 $\mathrm{K} / \mathrm{PID} / 2015$. Jenis penelitian yang digunakan dalam penelitian ini adalah library research atau penelitian hukum kepustakaan atau normatif, yaitu penelitian yang menggunakan data yang telah ada atau tersedia dalam bentuk data sekunder. 
Metode analisis data yang digunakan dalam penelitian ini adalah deskriptif, yaitu mengumpulkan semua data yang diperlukan kemudian menghubungkannya dengan permasalahan yang ada dan dianalisis berdasarkan teori hukum yang dihubungkan dengan masalah yang diteliti, kemudian data tersebut disistematisasikan dan selanjutnya dianalisis untuk menjadi dasar dalam mengambil kesimpulan.

\section{Hasil Penilitian dan Pembahasan}

Keabsahan Akta yang Dibuat di Hadapan Notaris yang Mengandung Unsur Tindak Pidana Pemalsuan Pada Putusan Pengadilan Nomor 1003 K/PID/2015

Untuk membuktikan suatu akta tersebut sah atau tidak sah dalam penelitian ini, digunakan asas praduga sah. Menurut Habib Adjie, dalam bukunya yang berjudul Sanksi Perdata dan Administrasi Terhadap Notaris sebagai pejabat publik, asas ini dapat dipergunakan untuk menilai akta Notaris, yaitu akta Notaris harus dianggap sah sampai ada pihak yang menyatakan akta tersebut tidak sah. Untuk menyatakan atau menilai akta tersebut tidak sah harus dengan gugatan ke Pengadilan Umum. ${ }^{9}$

Selama dan sepanjang gugatan berjalan sampai dengan ada keputusan pengadilan yang mempunyai kekuatan hukum tetap, maka akta Notaris tetap sah dan mengikat para pihak atau siapa saja yang berkepentingan dengan akta tersebut. Akta autentik yang dibuat oleh atau di hadapan Notaris harus dianggap sah dan mengikat para pihak sebelum dapat dibuktikan ketidakabsahan dari aspek lahiriah, formal dan materil akta autentik tersebut. ${ }^{10}$

Akta Nomor 149, 30 Maret 2011 merupakan perjanjian kerjasama yang dibuat di hadapan Notaris Neni Sanitra, dengan para pihaknya yaitu:

1. Daniel Freddy Sinambela, bertindak selaku Direktur Perseroan Terbatas Bonita Indah (PT. Bonita Indah), selanjutnya disebut Pihak Pertama.

2. Bonar Saragih dan Mangapul, selanjutnya disebut Pihak Kedua.

Pihak pertama dan pihak kedua telah sepakat untuk mengikuti tender jasajasa penyediaan kendaraan ringan tanpa jasa pengemudi pada PT. Chevron Pacific

${ }^{9}$ Habib Adjie, Sanksi Perdata \& Administratif ..., Op., Cit., hlm. 80.

${ }^{10} \mathrm{Ibid}$. 
Indonesia. Untuk keperluan kerjasama ini, pihak pertama menyediakan Perusahaan, segala administrasi dan izin-izin yang dimiliki pihak pertama untuk melaksanakan kontrak tersebut, sedangkan pihak kedua memasukkan/ menyediakan modal.

Hasil kesepakatan tersebut oleh Notaris Neni Sanitra kemudian dibuat doslag atau draf perjanjian kerja sama (minuta akta Nomor 149, 30 Maret 2011). Setelah doslag atau draf perjanjian kerjasama selesai dibuat, kemudian Notaris Neni Sanitra menyerahkan draf tersebut kepada Pihak Pertama dan Pihak Kedua untuk dibaca dan dipelajari. Ketika Pihak Pertama membaca dan mempelajari draft perjanjian tersebut, ternyata pada Pasal 7 disebutkan bahwa yang menerima imbalan jasa fee berupa 4 unit mobil diakhir pekerjaan dan fee berupa uang sebesar Rp. 5.000.000,00 per bulannya adalah Pihak Kedua, padahal seharusnya yang menerima adalah Pihak Pertama, sehingga Pihak Pertama menelepon Notaris Neni Sanitra dan mengatakan bahwa pada Pasal 7 draft minuta akta Nomor 149, 30 Maret 2011 terdapat kekeliruan, tolong dicek kembali, seharusnya Pihak Pertama yang mendapatkan fee berupa uang dan 4 unit mobil.

Setelah draft minuta akta Nomor 149, 30 Maret 2011 diperbaiki, Notaris Neni Sanitra kemudian membuat Minuta Akta Nomor 149 dengan bunyi Pasal 7 yang telah dirubah sesuai permintaan Pihak Pertama dan pada 30 Maret 2011 Minuta Akta Nomor 149, 30 Maret 2011 tersebut diparaf dan ditandatangani oleh Pihak Pertama dan Pihak Kedua.

Ternyata tanpa sepengetahuan Pihak Pertama, pada Pasal 4, Pasal 6, dan Pasal 9 yang pada awalnya disebutkan Pihak Pertama telah berubah menjadi Pihak Kedua. Notaris Neni Sanitra memerintahkan salah satu karyawannya, yaitu Febriani Eka Putri untuk merubah dengan cara Pihak Pertama dalam Pasal 4, Pasal 6, dan Pasal 9 dihapus dengan menggunakan penghapus kemudian diketik ulang menggunakan mesin ketik menjadi Pihak Kedua, dengan alasan perubahan tersebut Notaris Neni Sanitra lakukan untuk menyesuaikan perubahan pada Pasal 7 yang juga dirubah menggunakan mesin ketik, selain itu, Notaris Neni Sanitra juga ada pencoretan pada Pasal 6. 
Peraturan-peraturan hukum yang berkaitan dengan akibat hukum suatu akta yang dalam pembuatannya melanggar ketentuan peraturan perundangundangan yang berlaku berakibat akta Notaris dapat diajukan pembatalan, karena merupakan suatu tindakan yang mengandung cacat prosedur, maka konsekuensi hukum akta Notaris menjadi: ${ }^{11}$

1. Dapat dibatalkan (verniegbaar)

2. Batal demi hukum (nietigheid van rechtswege)

3. Mempunyai kekuatan pembuktian sebagai akta di bawah tangan

4. Dibatalkan oleh para pihak sendiri

5. Dibatalkan oleh putusan pengadilan yang telah mempunyai kekuatan hukum tetap karena penerapan asas praduga sah.

Berdasarkan Putusan Mahkamah Agung Nomor 1003 K/PID/2015 jo. Putusan Nomor 247/Pdt.G/2016/PN.Pbr, akta Nomor 149, 30 Maret 2011 dinyatakan sah dan berharga menurut hukum, namun dari segi kekuatan pembuktiannya, yang semula akta autentik terdegradasi menjadi akta di bawah tangan karena telah melanggar Pasal 48, 49, 50, dan 51 UUJN-P.

\section{Tanggung Jawab Notaris Terhadap Akta yang Dibuat di Dadapannya yang Mengandung Unsur Tindak Pidana Pemalsuan}

\section{Tanggung Jawab Notaris Secara Pidana}

Pertanggungjawaban pidana tidak mungkin tercipta jika pada diri orang yang melakukan tindak pidana tidak terdapat kesalahan. Kesalahan menjadi titik sentral konsep pertanggungjawaban pidana. ${ }^{12}$ Oleh karena itu, adigum yang sangat terkenal 'tiada pidana tanpa kesalahan" harus direformulasi menjadi "tiada pertanggungjawaban pidana tanpa kesalahan", artinya seseorang baru dapat dimintai pertanggungjawaban pidana atas tindak pidana yang dilakukan jika pada diri orang itu terdapat kesalahan. ${ }^{13}$

Perumusan tentang tanggung jawab pidana Notaris yang melanggar peraturan perundang-undangan tidak diatur secara khusus di dalam UUJN. Walaupun demikian, bukan berarti Notaris tidak dapat dijatuhi sanksi hukum

${ }^{11}$ Habib Adjie, Sanksi Perdata \& Administratif ..., Op., Cit., hlm. 81.

${ }^{12}$ Cynthia H. Finn, "The Responsible Corporate Officer, Criminal Liability, and Mens Rea: Limitations on the RCO Doctrine", The American University Law Review, Vol. 46, 1996, hlm. 548. Dikutip dari Hanafi Amrani dan Mahrus Ali, Sistem Pertanggungjawaban Pidana: Perkembangan dan Penerapan, Cetakan ke-1, Raja Grafindo Persada, Jakarta, 2015, hlm. 23.

${ }^{13}$ Ibid. 
pidana. Akta yang telah dibuat oleh atau di hadapan Notaris apabila memuat unsur sebagai tindak pidana, menimbulkan kerugian bagi para pihak, maka Notaris patut diduga telah melakukan atau turut serta dalam melakukan atau membantu melakukan suatu tindak pidana.

Pada kasus yang menimpa Notaris Neni Sanitra yang didakwa oleh Penuntut Umum telah melanggar Pasal 264 ayat (1) KUHP yang unsur-unsurnya sebagai berikut:

a. Barang Siapa

Yang dimaksud dengan pengertian barang siapa adalah setiap orang sebagai subyek hukum yang telah didakwa melakukan suatu tindak pidana dan memiliki kemampuan untuk bertanggung jawab atas setiap perbuatan yang dilakukannya.

Orang sebagai subyek hukum yang telah di hadapkan ke depan persidangan sebagai terdakwa oleh Jaksa/ penuntut dalam perkara ini adalah bernama Neni Sanitra, S.H., M.Kn. terdakwa adalah subyek hukum yang sehat jasmani dan rohani sehingga dipandang mampu bertanggungjawab atas setiap perbuatan yang dilakukannya, oleh karena itu Majelis Hakim berpendapat unsur "barang siapa" telah dipenuhi.

b. Membuat surat palsu atau memalsukan surat Yang dimaksud dengan membuat surat palsu adalah membuat surat yang isinya bukan semestinya (tidak benar), atau membuat surat sedemikian rupa sehingga menunjukkan asal surat itu tidak benar.

Yang dimaksud dengan memalsu surat adalah mengubah sedemikian rupa, sehingga isinya menjadai lain dari isi yang asli atau sehingga surat itu menjadi lain dari pada yang asli. Dapat pula dilakukan dengan jalan mengurangkan, menambah atau merubah sesuatu dari surat itu.

Pada kasus ini, Notaris Neni Sanitra telah merubah Pasal 4,6 dan 9. Padahal yang hanya di setujui untuk dirubah oleh Daniel Freddy Sinambela hanyalah Pasal 7 saja. Karena adanya penyangkalan dari salah satu pihak, maka dapat disimpulkan bahwa isi akta tersebut bukan kehendak dari semua pihak, maka unsur memalsukan surat terpenuhi.

c. Yang dapat menimbulkan sesuatu hak, suatu perikatan (kewajiban) atau pembebasan hutang, atau yang diperuntukkan sebagai bukti daripada sesuatu hal.

Pada unsur ini terdapat beberapa alternatif tujuan dari pemalsuan akta, yaitu menimbulkan sesuatu hak, atau menimbulkan sesuatu perikatan (kewajiban) atau pembebasan hutang, atau diperuntukkan sebagai bukti daripada sesuatu hal. Jika salah satu dari beberapa tujuan itu terpenuhi, maka dapat dikatakan unsur ini telah terpenuhi.

Tindakan perubahan yang dilakukan oleh Notaris Neni Sanitra terhadap isi Pasal 4,6,7 dan 9 Akta Nomor 149 tanggal 30 Maret 2011 telah merubah hak 
dan kewajiban antara pihak Pertama dan Pihak Kedua. Akibatnya, perubahan tersebut telah mendatangkan hak pada salah satu pihak dan menghilangkan hak pada pihak yang lainnya, Maka unsur ini pun terpenuhi.

d. Dengan maksud akan menggunakan atau menyuruh orang lain menggunakan surat tersebut seolah-olah surat itu asli dan tidak dipalsukan Kata "menggunakan" ialah dianggap menyerahkan akta itu kepada orang lain yang harus mempergunakan lebih lanjut atau menyerahkan akta itu di tempat dimana akta tersebut harus dibutuhkan. Pada persidangan tingkat pertama, terungkap bahwa Notaris Neni Sanitra telah menyerahkan salinan akta nomor 149 tersebut kepada pihak kedua, dengan demikian unsur ini telah terpenuhi.

e. Jika penggunaan tersebut dapat menimbulkan kerugian

Kerugian disini tidak saja meliputi kerugian materil, akan tetapi juga kerugian di lapangan kemasyarakatan, kesusilaan, kehormatan, dan sebagainya. Atas perbuatan Notaris Neni Sanitra yang telah merubah isi perjanjian, yaitu Pasal 4, 6, 7 dan 9 akta Nomor 149 , maka telah merubah pula hak dan kewajiban antara pihak pertama dan pihak kedua. Pihak pertama telah dirugikan, yaitu telah kehilangan haknya untuk memimpin kerjasama tersebut, dengan demikian, unsur inipun terpenuhi.

Berdasarkan unsur-unsur yang terkandung dalam Pasal 264 ayat (1) di atas telah terpenuhi, maka Mahkamah Agung menyatakan terdakwa Neni Sanitra terbukti secara sah dan meyakinkan bersalah melakukan tindak pidana pemalsuan surat autentik dan di pidana penjara selama 1 (satu) tahun.

\section{Tanggung Jawab Notaris Secara Perdata}

Penggantian biaya, ganti rugi atau bunga dapat dituntut terhadap Notaris dengan didasarkan pada suatu hubungan hukum antara Notaris dengan para pihak yang menghadap Notaris. Jika ada pihak yang merasa dirugikan sebagai akibat langsung dari suatu akta Notaris, maka yang bersangkutan dapat menuntut secara perdata.

Pertanggungjawaban Notaris atas pelanggaran yang telah dilakukannya, dapat digugat di Pengadilan. Gugatan dapat langsung ditujukan kepada Notaris sebagai tergugat ${ }^{14}$ tunggal, dan bisa sebagai turut tergugat. Atas perbuatan Notaris Neni Sanitra yang telah terbukti secara sah dan bersalah melakukan Tindak Pidana Pemalsuan Akta Autentik berdasarkan Putusan Pengadilan Nomor 1003

\footnotetext{
${ }^{14}$ Tergugat atau sering juga disebut Geddage atau Dependent, yaitu orang atau badan hukum yang terhadapnya diajukan gugatan atau tuntutan hak, dikutip dari M. Luthfan Hadi Darus, Op., Cit., hlm. 74.
} 
K/PID/2015, maka pada 19 Oktober 2016 PT. Bonita Indah (selaku penggugat) menggugat Notaris Neni Sanitra (selaku tergugat), Bonar Saragih (selaku turut tergugat I) serta Mangapul (selaku turut tergugat II) ke Pengadilan Negeri Pekanbaru.

Majelis Hakim pada perkara ini mempertimbangkan eksepsi tergugat, yaitu tentang gugatan penggugat nebis in idem. Dasar dari asas Nebis In Idem adalah Pasal 1917 KUH Perdata, yang menyatakan: "Kekuatan sesuatu putusan Hakim yang telah memperoleh kekuatan mutlak tidaklah lebih luas daripada sekedar mengenai soal putusannya. Untuk dapat memajukan kekuatan itu, perlulah bahwa soal yang dituntut adalah sama; lagi pula dimajukan oleh dan terhadap pihak-pihak yang sama di dalam hubungan yang sama pula". ${ }^{15}$

Subjek, Objek dan alasan serta tuntutan Penggugat dalam perkara Nomor 247/Pdt.G/2016/PN.Pbr sama dengan perkara berdasarkan putusan Pengadilan Negeri Pekanbaru Nomor 132/PDT.G/2011/PN.Pbr jo. Putusan Pengadilan Tinggi Riau Nomor 88/PDT/PTR jo. Putusan Mahkamah Agung Nomor 2807 K/Pdt/2013.

Oleh karena gugatan penggugat nebis in idem, maka majelis hakim menyatakan:

a. gugatan penggugat tidak dapat diterima (Niet Onvankelijverklaard);

b. menghukum penggugat untuk membayar perkara yang sampai hari ini ditetapkan sejumlah Rp. 1.985.000,- (satu juta Sembilan ratus delapan puluh lima ribu rupiah). ${ }^{16}$

\section{Tanggung Jawab Notaris Secara Adminisratif}

Secara garis besar, sanksi administratif dapat dibedakan menjadi 3 macam, yaitu: ${ }^{17}$

a. Sanksi Reparatif

Sanksi ini ditujukan untuk perbaikan atas pelanggaran tata tertib hukum. Dapat berupa penghentian perbuatan terlarang, kewajiban perubahan sikap/ tindakan

\footnotetext{
${ }^{15}$ R. Subekti dan R. Tjitrosudibio, Kitab Undang-undang Hukum Perdata, Cetakan ketiga puluh satu, PT Pradnya Paramita, Jakarta, 2001, hlm. 485.

16 Putusan Pengadilan Negeri Pekanbaru pada tingkat pertama, PT. Bonita Indah v. Neni Sanitra, Bonar Saragih, dan Mangapul, Nomor: 247/Pdt.G/2016/PN.Pbr, hlm. 44.

${ }^{1717}$ M. Luthfan Hadi Darus, Hukum Notariat dan Tanggung Jawab Jabatan Notaris, Cetakan Pertama, UII Press, Yogyakarta, 2017, hlm. 60.
} 
sehingga tercapai keadaan semula yang ditentukan, tindakan memperbaiki sesuatu yang berlawanan dengan aturan.

b. Sanksi Punitif

Sanksi yang bersifat menghukum, merupakan beban tambahan. Sanksi hukuman tergolong ke dalam pembalasan, dan tindakan preventif yang menimbulkan kekuatan kepada pelanggar yang sama atau mungkin pelanggar0pelanggar lainnya.

c. Sanksi Regresif

Sanksi regresif sebagai reaksi atas suatu ketidaktaatan, dicabutnya hak atas sesuatu yang diputuskan menurut hukum, seolah-olah dikembalikan kepada keadaan hukum yang sebenarnya sebelum keputusan diambil.

Akibat dari pelanggaran yang dilakukan oleh Notaris, maka Notaris harus bertanggungjawab secara administrasi. Menurut UUJN sanksi administrasi terdiri dari 5 sanksi, yaitu: ${ }^{18}$
a. Teguran lisan;
b. Teguran tertulis;
c. Pemberhentian sementara;
d. Pemberhentian dengan hormat, atau
e. Pemberhentian tidak hormat.

Pada kasus yang menjerat Notaris Neni Sanitra ini, diketahui bahwa isi perjanjian diubah secara sepihak oleh Notaris Neni Sanitra. Atas temuan itu, pada 10 Juli 2012, PT. Bonita Indah mengadukan aksi Notaris Neni Sanitra kepada Majelis Pengawas Daerah (MPD) Kota Pekanbaru, dengan nomor surat W4.MPDN.07.01-1677, kemudian MPD menindaklanjuti laporan tersebut sampai kepada Majelis Pengawas Wilayah (MPW) Notaris Provinsi Riau. Notaris Neni Sanitra dinyatakan telah melanggar Pasal 48 ayat (1) UUJN-P. ${ }^{19}$

Kemudian Pada 9 November 2012, Majelis Pengawas Notaris Wilayah Provinsi Riau melalui putusan Nomor: 02/PTS/MJ/PWN.Prov. Riau/IX/2012 memutuskan dengan amar putusan sebagai berikut:20

a. Menyatakan Pengaduan pelapor Daniel Freddy Sinambela dapat diterima;

b. Menghukum saudari Neni Sanitra, Notaris Kota Pekanbaru dengan sanksi teguran lisan, karena telah menghapus, menindih dan menggantinya

\footnotetext{
${ }^{18}$ Pasal 85 UUJN.

${ }^{19} \mathrm{https}$ // m.merdeka.com/peristiwa/jaksa-cokok-notaris-pemalsu-akta-perjanjian-kerjasama-dipekanbaru.html// diakses tanggal 9 November 2017.

${ }^{20}$ Putusan Mahkamah Agung Republik Indonesia pada tingkat Kasasi dalam Perkara PT Bonita Indah v. Neni Sanitra, Nomor 1003 K/PID/2015, hlm. 23.
} 
dengan yang lain, terhadap Pasal 4, Pasal 6, dan Pasal 7 akta Nomor 149 tanggal 30 Maret 2011, sehingga Notaris Neni Sanitra dinyatakan telah melanggar Pasal 48 ayat (1) UUJN-P yang berbunyi sebagai berikut:

"Isi akta tidak boleh dirubah atau ditambah, baik berupa penulisan tindih, penyisipan, pencoretan, atau penghapusan dan mengganti dengan yang lain".

Sanksi-sanksi berbentuk simbolis seperti peringatan lisan dan peringatan tertulis yang berfungsi sebagai tolak ukur untuk menunjukkan tingkat keseriusan pelanggaran yang dilakukan oleh Notaris. Tujuan dari adanya sanksi ini adalah koreksi, yaitu dengan adanya tahap peringatan yang jelas tentang apa yang diperlukan dan akibat-akibat ketidakpatuhan. ${ }^{21}$

\section{Penutup}

Berdasarkan Putusan Mahkamah Agung Nomor 1003 K/PID/2015 jo. Putusan Nomor 247/Pdt.G/2016/PN.Pbr, akta Nomor 149, 30 Maret 2011 dinyatakan sah dan berharga menurut hukum, namun dari segi kekuatan pembuktiannya, yang semula akta autentik terdegradasi menjadi akta di bawah tangan karena telah melanggar Pasal 48, 49, 50, dan 51 UUJN-P.

Dari segi pertanggungjawaban pidana, pada putusan Nomor 1003 K/PID/2015 yang menyatakan terdakwa Neni Sanitra terbukti secara sah dan meyakinkan bersalah melakukan tindak pidana pemalsuan surat autentik sehingga Notaris Neni Sanitra dipidana penjara selama 1 tahun. Dari segi pertanggungjawaban perdata, pada perkara Nomor 247/Pdt.G/2016/PN.Pbr, gugatan yang ditujukan kepada Notaris Neni Sanitra nebis in idem, yaitu Subjek, Objek dan alasan serta tuntutan Penggugat dalam perkara Nomor 247/Pdt.G/2016/PN.Pbr sama dengan perkara berdasarkan putusan Pengadilan Negeri Pekanbaru Nomor 132/PDT.G/2011/PN.Pbr jo. Putusan Pengadilan Tinggi Riau Nomor 88/PDT/PTR jo. Putusan Mahkamah Agung Nomor 2807 $\mathrm{K} / \mathrm{Pdt} / 2013$, sehingga hakim menyatakan gugatan penggugat tidak dapat diterima. Pertanggungjawaban dari segi administratif, yaitu Majelis Pengawas

${ }^{21}$ M. Luthfan Hadi Darus, Op., Cit., hlm. 140. 
Notaris Wilayah Provinsi Riau melalui putusan Nomor: 02/PTS/MJ/PWN.Prov. Riau/IX/2012, menghukum Neni Sanitra, Notaris Kota Pekanbaru dengan sanksi teguran lisan, karena telah menghapus, menindih dan menggantinya dengan yang lain, terhadap Pasal 4, Pasal 6, dan Pasal 7 akta Nomor 149, 30 Maret 2011, sehingga Notaris Neni Sanitra dinyatakan telah melanggar Pasal 48 ayat (1) UUJN-P.

\section{Daftar Pustaka}

\section{Buku}

Adjie, Habib, Kebatalan dan Pembatalan Akta Notaris, Cetakan Kesatu, Refika Aditama, Bandung, 2011.

Amrani, Hanafi dan Ali, Mahrus, Sistem Pertanggungjawaban Pidana: Perkembangan dan Penerapan, Cetakan ke-1, Raja Grafindo Persada, Jakarta, 2015.

Darus, M. Luthfan Hadi, Hukum Notariat dan Tanggung Jawab Jabatan Notaris, Cetakan Pertama, UII Press, Yogyakarta, 2017.

Hamzah, Andi, dan Dahlan, Irdan, Upaya Hukum Dalam Perkara Pidana, Bina Aksara, Jakarta, 1987.

Harahap, M. Yahya, Pembahasan Permasalahan dan Penerapan KUHAP: Pemeriksaan Sidang Pengadilan, Banding, Kasasi dan Peninjauan Kembali, Edisi kedua, Sinar Grafika, Jakarta, 2005.

Lamintang, P.A.F. dan Lamintang, Theo, Delik-Delik Khusus Kejahatan Membahayakan Kepercayaan Umum Terhadap Surat, Alat Pembayaran, Alat Bukti, dan Peradilan, Cetakan Pertama, Edisi Kedua, Sinar Grafika, Jakarta, 2009.

Moeljatno, KitabUndang-Undang Hukum Pidana, Cetakan Kedua puluh delapan, Bumi Aksara, Jakarta, 2009.

Subekti. R dan Tjitrosudibio. R, Kitab Undang-undang Hukum Perdata, Cetakan ketiga puluh satu, PT Pradnya Paramita, Jakarta, 2001.

Supriadi, Etika \& Tanggung Jawab Profesi Hukum Di Indonesia, Cetakan Keenam, Sinar Grafika, Jakarta, 2016.

\section{Putusan Pengadilan}

PT. Bonita Indah v. Neni Sanitra, Putusan Mahkamah Agung Nomor: 1003 $\mathrm{K} / \mathrm{PID} / 2015$.

PT. Bonita Indah v. Neni Sanitra, Bonar Saragih, dan Mangapul, Putusan Pengadilan Negeri Pekanbaru pada tingkat pertama Nomor: 247/Pdt.G/2016/PN.Pbr.

\section{Internet}

https:/ / m.merdeka.com/peristiwa/jaksa-cokok-notaris-pemalsu-akta-perjanjiankerjasama-di-pekanbaru.html / / diakses tanggal 9 November 2017. 